\title{
ISLAMSKI RUCH UZBEKISTANU - OD LOKALNEGO EKSTREMIZMU DO PAŃSTWA ISLAMSKIEGO
}

Mirosław JAREMBA

\section{ABSTRACT}

\section{ISLAMIC MOVEMENT OF UZBEKISTAN - FROM LOCAL EXTREMISM TO ISLAMIC STATE}

This article presents one of the terrorist group in Central Asia. Islamic Movement of Uzbekistan is a fundamentalist Islam organization acting at first in Uzbekistan and then going beyond even to Afghanistan with its actions. This article will present the causes of existence of Islamic extremism in Central Asia, events which were enhancing the ideas of radicalism, as i.e. civil war in Tajikistan (1992-1997) or the Batken crises (1999, 2000), specific IMU actions or circumstances of connection to so-called Islamic State. It is the analysis of extremism in Central Asia and the explanation of this phenomenon; moreover the role of external factors in Islamic mobilization in the region and how the Organized crime works there.

\section{KEYWORDS:}


Pojawienie się zorganizowanych grup ekstremistycznych w Azji Centralnej sięga początku lat osiemdziesiątych XX wieku. Zaważył na nich zarówno komunizm, jak i na późniejszym etapie wyzwoleńczy duch czasów pierestrojki. Istotnym czynnikiem, który wpłynął na rodzące się niezadowolenie mieszkańców byłego ZSRR, była wojna w Afganistanie. Zaczęły tworzyć się niewielkie komórki ruchu oporu, które dążyły do wprowadzenia nowego porządku w społeczeństwie oraz zwiększenia wpływu religii na relacje społeczne. Ich głównym celem było wprowadzenie szariatu w sfery życia społecznego oraz traktowanie go jako obowiązująca norma prawna ${ }^{2}$.

Początek lat dziewięćdziesiątych to okres rozpadu ZSRR, który zbiegł się $\mathrm{z}$ momentem rozkwitu wojującego islamu, określanego jako wahabizm ${ }^{3}$. Ponadto w tym okresie na terenie Azji Centralnej miały miejsce wydarzenia, które potęgowały idee radykalizmu, jak na przykład wojna domowa w Tadżykistanie (1992-1997) czy kryzysy batkeńskie $(1999,2000)^{4}$. Z upływem czasu sytuacja w Dolinie Fergańskiej zaczęła ulegać zmianie. Na gruncie społecznego kryzysu zaczęły wyrastać organizacje islamistyczne, z których istotną rolę odegrała grupa Adolat. Na jej czele stało dwóch ekstremistów: Tohir Juldaszew i Dżuma Namangani. Prezydent Uzbekistanu, Islom Karimow, zdając sobie sprawę z zagrożenia, jakie stanowiła rosnąca w siłę grupa Adolat, zlikwidował w 1992 roku organizację, a członków skazał na kary więzienia ${ }^{5}$.

Po roku 1992 Juldaszew i Namangani zbiegli do Tadżykistanu, by przygotować się do tadżyckiej wojny domowej u boku Islamskiej Partii Odrodzenia (IPO). Tohir Juldaszew do momentu założenia IRU w roku 1998 podróżował po krajach arabskich (między innymi Arabia Saudyjska, Zjednoczone Emiraty Arabskie) i Kaukazie, by potem propagować w rejonie Azji Centralnej idee panislamizmu. Za główny cel wyznaczył sobie pozyskanie nowych bojowników oraz funduszy na późniejszą działalność. Z kolei drugi czołowy bojownik organizacji, Dżuma Namangani, osiedlił się w Tadżykistanie i kierował tam małą grupą ochotników, której członkowie, podobnie jak on, musieli opuścić Dolinę Fergańską, działając u boku IPO w tadżyckiej wojnie domowej (1992-1997). Po zakończonych działaniach zbrojnych w Tadżykistanie Juldaszew

Szariat - religijne prawo muzułmańskie oparte na Koranie i hadisach.

J. Lang, Zbrojni radykatowie islamscy z Azji Centralnej, Warszawa 2013, s. 8.

Wahabizm - to fundamentalistyczny ruch religijno-polityczny dążący do oczyszczenia islamu z wszelkich naleciałości, Y. Thoraval, Stownik cywilizacji muzutmańskiej, Paryż 2004, s. 306.

K. Strachota, M. Falkowski, Dżihad i nowa wielka gra. Paradoksy zagrożenia wojującym islamem w Azji Centralnej, Warszawa 2010, s. 8-18.

J. Lang, dz. cyt., s. 9-11. 
i Namangani wrócili do Uzbekistanu z zamiarem rozprawienia się z bezwzględną dyktaturą Karimowa, którego brutalna władza nie oszczędziła także ich bliskich .

Wydaje się, że na bazie tych doświadczeń w połowie 1998 roku obaj bojownicy utworzyli Islamski Ruch Uzbekistanu (IRU). Ruch ten miał na celu obalenie dyktatury Karimowa i wprowadzenie struktur państwa religijnego. W dniu 16 lutego 1999 roku w pobliżu siedziby Rady Ministrów Uzbekistanu doszło do wybuchów samochodów pułapek. Władze oskarżyły członków IRU o zorganizowanie zamachów i nasiliły represje wobec radykałów islamskich. Część z nich zbiegła do Tadżykistanu. Stamtąd, mimo nacisków i represji prezydenta Uzbekistanu, przywędrowali do Kotliny Fergańskiej .

Grupa wojowników Namanganiego odegrała istotną rolę w kryzysie państwa uzbeckiego oraz w krzewieniu wojującego islamu w Azji Centralnej. Grupa ta odpowiedzialna jest za dwa kryzysy batkeńskie (1999, 2000), w trakcie których wtargnęła przez Kirgistan na terytorium Uzbekistanu i walczyła z tamtejszymi wojskami ${ }^{8}$. W tym okresie intensywnie rekrutowano nowych bojowników do IRU z Kirgistanu, Tadżykistanu, Afganistanu i Pakistanu. Budziło to wyraźne niezadowolenie ówczesnych władz, które wprowadziły liczne represje. Pomimo tak zdecydowanych reakcji nie udało się jednak zahamować działalności rosnącego w siłę IRU. Pod jego kontrolą pozostawały najważniejsze szlaki przemytu narkotyków w Afganistanie, które wiodły z Azji Centralnej do Europy ${ }^{9}$.

Do wspomnianego wcześniej pierwszego kryzysu batkeńskiego doszło w 1999 roku. Jego bezpośrednią przyczyną była chęć przejęcia spornych terytoriów (Soch i Woruch) przez IRU. Pomiędzy krajami zainteresowanymi (Kirgistan, Tadżykistan, Uzbekistan) tymi regionami a bojownikami IRU toczyły się liczne walki. Na terenach tych zdarzały się częste uprowadzenia ${ }^{10}$, na przykład lokalnych urzędników, zwykle dla okupu ${ }^{11}$.

Drugi kryzys batkeński (2000) to wydarzenie zbrojne na znacznie większą skalę. Działalność ruchu obejmowała obszar od gór Batkenu, poprzez zachodni i północny kraniec Tadżykistanu, obwód surchandaryjski, kończąc w rejonach Taszkentu. Do jednego z najbardziej dramatycznych pogromów tamtego okresu doszło 11 sierpnia 2000 roku, kiedy to IRU zorganizował zasadzkę w wąwozie Korbacha, w której zginęło 28 osób $^{12}$.

A. Rashid, Dżihad. Narodziny wojującego islamu w Azji Środkowej, tłum. A. Falkowska, M. Falkowski, Warszawa 2003, s. 171-185.

S. Zapaśnik, Walczący islam w Azji Centralnej, Torun 2014, s. 109-111.

G. Zasada, Islam w Uzbekistanie [w:] Islam na obszarze postradzieckim, red. A. Łubaszewska, Warszawa 2003. S. Zapaśnik, dz. cyt., s. 112.

Najgłośniejsze było porwanie czterech japońskich geologów, po zapłaceniu okupu uwolniono zakładników. A. Rashid, dz. cyt., s. 196-205.

Tamże, s. 205-214. 
$\mathrm{Na}$ arenie międzynarodowej IRU zaistniał po 2000 roku, czyli w okresie drugiego kryzysu batkeńskiego. Prawdopodobnie podczas toczących się walk uprowadzono i przetrzymywano czterech amerykańskich alpinistów. Nigdy nie potwierdzono prawdziwości tego zdarzenia. Jednakże w aspekcie zarówno prowadzonego handlu narkotykami, jak i powiązań z Osamą bin Ladenem wydarzenia te przyczyniły się do tego, że IRU został wpisany na listę organizacji terrorystycznych ${ }^{13}$.

Po wydarzeniach drugiego kryzysu batkeńskiego członkowie IRU przenieśli się na tereny Afganistanu i wcielili się w szeregi Al-Kaidy. W wyniku prowadzenia działań zbrojnych doszło do obalenia walczących talibów, głównie przez siły zbrojne USA. W okresie tym wojownicy IRU przenieśli się na tereny Pakistanu. Stworzyli tam strukturę terrorystyczną działającą u boku talibów ${ }^{14}$, skupiając się głównie na rozwoju oraz propagowaniu idei ekstremistycznej.

Po śmierci Namanganiego w szeregach IRU dochodziło do licznych nieporozumień i wewnętrznych zatargów. Drugi lider ruchu, Tohir Juldaszew, nie był zwolennikiem polityki zawładnięcia Azją Centralną. Zdecydowanie inne poglądy w tej kwestii mieli zwolennicy zmarlego lidera, którzy wyraźnie demonstrowali zamiary ekspansji. $\mathrm{Z}$ powodu tych różnic w 2004 roku doszło do rozłamu w grupie. Od IRU odłączyła się grupa, która przybrała nazwę Islamskiej Unii Dżihadu (IUDż) i szybko podjęła własne działania terrorystyczne. Była odpowiedzialna za ataki na budynki rządowe w Taszkiencie oraz w Bucharze. Grupie tej przypisuje się serię samobójczych zamachów w stolicy przy budynkach ambasady USA i Izraela. Pierwotnie o przeprowadzenie zamach byli oskarżani członkowie IRU. Jednakże ostatecznie odpowiedzialnymi za to zdarzenie uważa się wojowników grupy IUDż ${ }^{15}$.

W 2009 roku po raz kolejny sytuacja w szeregach IRU zmieniła się. W wyniku ataku amerykańskiego samolotu bezpilotowego zginął Tohir Juldaszew. W rezultacie władzę objęli dowódcy nowego pokolenia ekstremistów ${ }^{16}$. Jedno z ostatnich spektakularnych działań tej grupy miało miejsce 8 czerwca 2014 roku. W zamachu terrorystycznym na lotnisko w Karaczi, które zostało doszczętnie zniszczone, zginęło 36 osób ${ }^{7}$.

Usman Gozi, obecny lider IRU, wydał w ostatnim czasie oświadczenie o przyłączeniu ruchu do struktur Państwa Islamskiego. Wiadomość ta przyczyniła

Tamże, s. 115.

M. Falkowski, J. Lang, Homo dżihadicus. Islam na obszarze byłego ZSRR a fenomen postsowieckich bojowników w Syrii i Iraku, Warszawa 2015, s. 23-24.

J. Lang, dz. cyt., s. 12-15.

Tamże, s. 16.

http://www.reuters.com/article/us-pakistan-militants-idUSKBNOEM14L20140611 [dostęp: 6.12.2015]. 
się do wprowadzenia nadzwyczajnych środków bezpieczeństwa w Uzbekistanie i w całej Azji Centralnej ${ }^{8}$.

W marcu 2015 roku niezależna grupa Uzbeków, w tym członkowie IRU, zaprzysięgli wierność Państwu Islamskiemu. Lokalny wojownik ruchu, Sadulla Urgenji, oświadczyl, że IRU uprowadziło 30 afgańskich żołnierzy. Był to odwet na tamtejszych służbach bezpieczeństwa za przejęcie kobiet wojujących w szeregach IRU. W Internecie umieszczono film ukazujący brutalną egzekucję afgańskich żołnierzy ${ }^{19}$.

Obecnie Islamski Ruch Uzbekistanu oraz Unia Islamskiego Dżihadu działają na obszarze Północnego Waziristanu, gdzie stanowią jedną z najważniejszych i najbardziej niebezpiecznych organizacji światowego dżihadu. Blisko związani z Al-Kaidą i Państwem Islamskim ściśle z nimi współpracują. Zasięg działania Islamskiego Ruchu Uzbekistanu zdecydowanie wykracza poza granice Afganistanu. Swoją strukturą sięgają między innymi terenów Tadżykistanu, Kirgistanu i Turkmenistanu. Ekspansywna działalność ruchu wskazuje na chęć objęcia kalifatem całej Azji Centralnej oraz obszaru Chorasanu ${ }^{20}$.

$18 \mathrm{http://www.mk.ru/politics/2014/10/06/islamskoe-dvizhenie-uzbekistana-zayavilo-o-prisoedinenii-}$ k-ig.html [dostęp: 6.12.2015].

19 http://www.rferl.org/content/uzbek-group-in-afghanistan-behead-afghan-soldier/26928658.html [dostęp: 6.12.2015].

20 T. Otłowski, Azja Centralna - kolejny front walki z islamizmem, Warszawa 2013, s. 4-6. 


\section{BIBLIOGRAFIA:}

„Исламское движение Узбекистана» заявило о присоединении к ИГ, http:// www.mk.ru/politics/2014/10/06/islamskoe-dvizhenie-uzbekistana-zayavilo-oprisoedinenii-k-ig.html [dostęp: 6.12.2015].

Arabowie. Stownik encyklopedyczny, red. M. M. Dziekan, Warszawa 2001.

Falkowski M., Lang J., Homo dżihadicus. Islam na obszarze byłego ZSRR a fenomen postsowieckich bojowników w Syrii i Iraku, Warszawa 2015.

Golovina M., Feared Uzbek Jihadists behind deadly Pakistan airport attack, http:// www.reuters.com/article/us-pakistan-militants-idUSKBNOEM14L20140611 [dostęp: 6.12.2015].

Lang J., Zbrojni radykałowie islamscy z Azji Centralnej, Warszawa 2013.

Otłowski T., Azja Centralna - kolejny front walki z islamizmem, Warszawa 2013.

Rashid A., Dżihad. Narodziny wojujacego islamu w Azji Środkowej, tłum. A. Falkowska, M. Falkowski, Warszawa 2003.

Strachota K., Falkowski M., Dżihad i nowa wielka gra. Paradoksy zagrożenia wojujacym islamem w Azji Centralnej, Warszawa 2010.

Thoraval Y., Stownik cywilizacji muzutmańskiej, Paryż 2004.

Uzbek Group In Afghanistan Pledge Allegiance To Islamic State, http://www.rferl. org/content/uzbek-group-in-afghanistan-behead-afghan-soldier/26928658.html [dostęp: 6.12.2015].

Zapaśnik S., Walczący islam w Azji Centralnej, Toruń 2014.

Zasada G., Islam w Uzbekistanie [w:] Islam na obszarze postradzieckim, red. A. Łubaszewska, Warszawa 2003. 